\title{
The clinicopathological spectrum of Rosenthal fibre encephalopathy and Alexander's disease: a case report and review of the literature
}

\author{
J Jacob, N J Robertson, D A Hilton
}

J Neurol Neurosurg Psychiatry 2003;74:807-810

Alexander's disease is a leucodystrophy that usually presents in early childhood, but can infrequently arise in adults. It is characterised pathologically by megalencephaly, demyelination, and the presence of numerous Rosenthal fibres. Most cases have been shown to be due to mutations in the gene encoding glial fibrillary acidic protein. In rare instances, numerous Rosenthal fibres have been found at autopsy in patients who have suffered protracted debilitating systemic illnesses, some with associated brain stem signs, and in very rare instances in patients with no apparent neurological abnormality. The term "Rosenthal fibre encephalopathy" is used to distinguish these cases from those of Alexander's disease. We report the first case of Rosenthal fibre encephalopathy in a young man with AIDS, and review the literature.

A lexander's disease is a sporadic disorder affecting central nervous system (CNS) white matter. It usually presents in infancy with megalencephaly, dementia, spasticity, and seizures, ${ }^{1}$ but may also present in later childhood and rarely in adulthood, ${ }^{23}$ where the disease progression may be slow and can cause clinical confusion with multiple sclerosis. ${ }^{4}$ Pathologically, Alexander's disease is characterised by eosinophilic cytoplasmic inclusions, termed Rosenthal fibres, within astrocyte processes, adjacent to areas of demyelination. ${ }^{5}$ Rosenthal fibres contain glial fibrillary acidic protein (GFAP), ubiquitin, and the heat shock proteins hsp-27 and $\alpha \beta$-crystallin. ${ }^{6-9}$ It has been postulated that they form as a consequence of a metabolic disturbance of astrocytes that in turn leads to the degradation of excessive amounts of glial filaments. ${ }^{10}$

There have been rare case reports of adults dying with a variety of systemic and neurological disorders who have been found at autopsy to have prominent Rosenthal fibre deposition, but without the clinical features or demyelinating lesions that are typical of Alexander's disease. ${ }^{11-13}$ In these cases the distribution of Rosenthal fibres is predominantly perivascular, subependymal, and subpial in location, resembling that seen in Alexander's disease, but largely confined to the brain stem. To distinguish these cases from those of Alexander's disease, the term "Rosenthal fibre encephalopathy" has been suggested, despite the lack of consistent clinical findings. ${ }^{12}$ We report a case of Rosenthal fibre encephalopathy in a young man with AIDS, an association that has hitherto not been reported.

\section{CASE REPORT}

A 33 year old man was diagnosed with AIDS after presenting with a six month history of weight loss and malaise associated with superficial lymphadenopathy, oral hairy leucoplakia, and molluscum contagiosum. Neurological examination was normal, but a magnetic resonance imaging (MRI) scan of the head disclosed several discrete enhancing intracerebral lesions. Haematological investigations revealed a neutropenia with a CD4 count of $0.03 \times 10^{9} / 1$ and a haemoglobin of $80 \mathrm{~g} / \mathrm{l}$. Lamivudine, zidovudine, zalcitabine, dapsone, and pyrimethamine were commenced. Six weeks later the patient represented with a severe occipital headache. Repeat MRI brain imaging showed the lesions had progressed. The patient was treated symptomatically with dexamethasone; he died five days later.

At postmortem examination, internal examination was restricted to the cranial cavity. The brain weighed $1688 \mathrm{~g}$ and appeared diffusely swollen. The leptomeninges were translucent. Coronal slices through the cerebral hemispheres revealed a macroscopically normal cortical ribbon. There was, however, some yellow discolouration of the white matter, particularly in the left frontal region, and softening and brown discolouration were seen in the left corpus striatum and caudate nucleus. Areas of yellow discolouration and softening were also noted in the midbrain and cerebellum.

Histological examination of the cerebellum revealed extensive infiltration with high grade malignant non-Hodgkin's lymphoma, which was confirmed to be of B cell type by strong immunocytochemical expression of the B cell marker CD79a. Lymphoma was also present within the left caudate nucleus, midbrain, and pons (fig lA). Scattered lymphoma cells showed nuclear signal following in situ hybridisation using probes directed against Epstein-Barr virus. ${ }^{14}$ In addition, multiple microglial nodules were seen throughout the cerebral cortex, cerebellum, and brain stem, and within some of them occasional cytomegalovirus (CMV) inclusions were seen, indicating a low grade CMV encephalitis (fig 1B).

An unexpected finding was the presence of numerous Rosenthal fibres in the brain stem. These were particularly numerous in subpial regions, where they were arranged perpendicularly to the pial surface, producing a pallisaded arrangement around blood vessels (fig lC). In addition Rosenthal fibres were present at nerve root entry zones in the brain stem, in subependymal regions of the floor of the fourth ventricle and, to a lesser extent, beneath the ependyma of the lateral vetricles. Rosenthal fibres were not found in other parts of the cerebrum or cerebellum. The Rosenthal fibres were strongly immunoreactive with antibodies to GFAP, ubiquitin, and $\alpha \beta$-crystallin (fig lD). Demyelination was not present, and the distribution of Rosenthal fibres was not related to other pathological changes in the brain.

Abbreviations: CNS, central nervous system; GFAP, glial fibrillary acidic protein; MRI, magnetic resonance imaging 

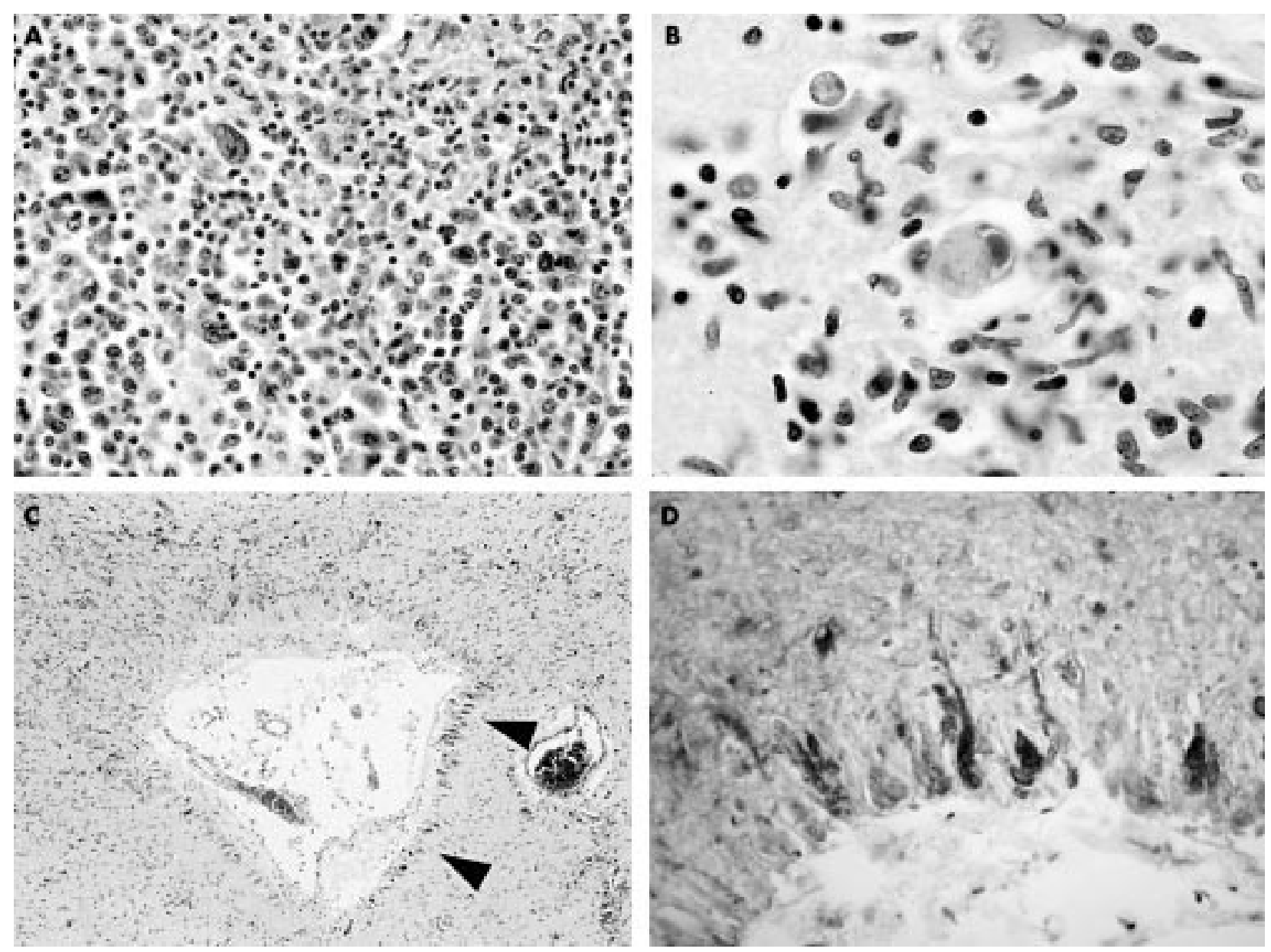

Figure 1 (A) High grade diffuse B cell lymphoma showing large pleomorphic lymphocytes. (B) Microglial nodule from cerebral cortex showing intranuclear inclusion typical of cytomegalovirus. (C) Midbrain showing pallisaded arrangement of Rosenthal fibres around blood vessels (arrowheads). (D) High power view of Rosenthal fibres showing $\alpha \beta$-crystallin immunoreactivity.

\section{DISCUSSION}

It is generally accepted that both Alexander's disease and Rosenthal fibre encephalopathy are atttributable to disorders of astrocytes, but the overlap between these two disorders has hindered attempts to define consensus clinicopathological criteria for each disease. This has led to misclassification of reported cases. To rectify this problem we sought to reclassify published cases in order to comply with stricter definitions of each disease. Typical adult onset Alexander's disease is characterised pathologically by the presence of diffuse Rosenthal fibres, and demyelinating and cavitating cerebral lesions, and clinically by progressive dementia, ataxia, spasticity, and seizures. ${ }^{12}$ Cases which display all the pathological characteristics of Alexander's disease, but apparently lack neurological involvement, have been classified in the latter category in view of the difficulty in ascertaining the rigour of the neurological evaluation. In contrast, Rosenthal fibre encephalopathy is typified by a preponderance of Rosenthal fibres in the brain stem without demyelination or accompanying clinical evidence of neurological involvement, often in the context of debilitating systemic illness. ${ }^{12}$ The presence of neurological signs in some of the latter cases can lead to confusion and misdiagnosis as Alexander's disease, but their presence can be readily explained in most of these cases by additional CNS pathology (see table 1).

The wide spectrum of clinical presentations in adult onset Alexander's disease and Rosenthal fibre encephalopathy is clear from a review of published cases. A Medline search from 1968 to the present, generated 15 publications and 25 patients (table 1). Of these, 15 patients had Alexander's disease and 10 patients (11 patients including the present case) could be classed as having Rosenthal fibre encephalopathy, using the above definitions. The age range of adult onset Alexander's disease was 23-61 years and 19-85 years for Rosenthal fibre encephalopathy. The male to female ratio for Alexander's disease was 0.5:1 and for Rosenthal fibre encephalopathy 0.8:1 (including this case). The clinical spectrum of adult onset Alexander's disease remains controversial, but atypical neurological presentations are also recognised; for example, palatal myoclonus has been described in one of the cases reported by Howard and colleagues, ${ }^{15}$ and in three of the cases of Schwankhaus and colleagues. ${ }^{16}$ In all other respects the clinical features of these cases conform well to other reported cases of adult onset Alexander's disease. Both groups identified familial versions of adult onset Alexander's disease, although Howard and colleagues ${ }^{15}$ avoided explicit use of this term, presumably because of the familial rather than sporadic incidence and the unusual presentation. Of the 15 cases classified as Alexander's disease, typical pathological changes were confirmed at postmortem examination in seven cases. In two other cases myelin pallor rather than frank demyelination was associated with Rosenthal fibre deposition. Pathological confirmation of Alexander's disesase was not obtained in four cases, all with familial presentations, as the diagnosis had been confirmed in the other siblings. ${ }^{15}{ }^{16}$ In only two cases were Rosenthal fibres the sole pathological finding, but the diagnosis in one of these cases was based on brain biopsy, which may not be representative because of sampling bias. In both instances a compelling case can be made for a diagnosis 
Table 1 Summary of published cases of adult onset Alexander's disease and Rosenthal fibre encephalopathy

\begin{tabular}{|c|c|c|c|c|}
\hline \multirow[b]{2}{*}{ Age and sex } & \multirow[b]{2}{*}{ Systemic disease [toxins/drugs] } & \multicolumn{2}{|l|}{ Neurological involvement } & \multirow[b]{2}{*}{ Postmortem CNS findings } \\
\hline & & Yes & No & \\
\hline \multicolumn{5}{|c|}{ Diagnosis of Alexander's disease } \\
\hline 27 Male $^{15}$ & & $\begin{array}{l}\text { Bulbar palsy, tongue fasciculations, } \\
\text { ataxia, spasticity }\end{array}$ & & - \\
\hline $32 \mathrm{Male}^{2}$ & $\begin{array}{l}\text { TB, intestinal obstruction, renal tract } \\
\text { infection [anti-TB drugs] }\end{array}$ & Bulbar palsy, ataxia, spasticity & & Diffuse RF, cavitating brain lesions \\
\hline $37 \mathrm{Male}^{23}$ & & Epilepsy, dementia, ataxia, spasticity & & Diffuse RF \\
\hline 39 Male $^{5}$ & & $\begin{array}{l}\text { Ataxia, aphasia, cranial polyneuropathy, } \\
\text { spasticity }\end{array}$ & & Diffuse RF, demyelination \\
\hline $61 \mathrm{Male}^{4}$ & & Spasticity, ataxia, nystagmus & & Diffuse RF and demyelination \\
\hline 23 Female $^{4}$ & $\begin{array}{l}\text { Hepatic and renal failure, alcoholic, } \\
\text { depression [alcohol/psychotropic drugs] }\end{array}$ & & + & $\begin{array}{l}\text { Diffuse RF and demyelination in dentate } \\
\text { nucleus }\end{array}$ \\
\hline 25 Female $^{15}$ & & $\begin{array}{l}\text { Palatal myoclonus, tongue fasciculation, } \\
\text { spasticity }\end{array}$ & & $\begin{array}{l}\text { *Brain stem and periventricular RF, } \\
\text { myelin pallor }\end{array}$ \\
\hline 26 Female $^{24}$ & & $\begin{array}{l}\text { Ataxia, spasticity, visual deficit, } \\
\text { dysphagia }\end{array}$ & & ${ }^{*}$ Cerebellar RF \\
\hline 29 Female $^{15}$ & & Ataxia, dysphonia, spastic monoparesis & & - \\
\hline 37 Female $^{4}$ & Asthma & Spasticity, ataxia, nystagmus & & RF and demyelination \\
\hline 39 Female $^{3}$ & Perinatal hypoxia & $\begin{array}{l}\text { Childhood seizures, ataxia, dementia, } \\
\text { spasticity, pseudobulbar palsy }\end{array}$ & & $\begin{array}{l}\text { Diffuse RF, demyelination, calcified } \\
\text { basal ganglia }\end{array}$ \\
\hline 43 Female $^{16}$ & & $\begin{array}{l}\text { Bulbar palsy, palatal myoclonus, ataxia, } \\
\text { urinary incontinence }\end{array}$ & & - \\
\hline 43 Female $^{25}$ & [alcohol/psychotropic drugs] & & + & Diffuse RF, demyelination \\
\hline 48 Female $^{16}$ & & $\begin{array}{l}\text { Diplopia, palatal myoclonus, spastic } \\
\text { quadriparesis, ataxia, urinary and faecal } \\
\text { incontinence }\end{array}$ & & Diffuse RF, myelin pallor, astrogliosis \\
\hline 49 Female $^{16}$ & & Bulbar palsy, palatal myoclonus & & - \\
\hline \multicolumn{5}{|c|}{ Diagnosis of Rosenthal fibre encephalopathy } \\
\hline 19 Male $^{26}$ & $\begin{array}{l}\text { Metastatic testicular carcinoma, intestinal } \\
\text { obstruction, septicaemia, low } \mathrm{Mg}^{2+} / \mathrm{PO}_{4}^{-} \\
\text {[i.v. feeding] }\end{array}$ & Seizures & & $\begin{array}{l}\text { Predominantly brain stem RF and central } \\
\text { pontine myelinolysis }\end{array}$ \\
\hline 22 Male $^{12}$ & $\begin{array}{l}\text { Schizophrenic, septicaemia, ARDS } \\
\text { [solvent abuse, antipsychotics analgesics, } \\
\text { procyclidine] }\end{array}$ & $\begin{array}{l}\text { Cognitive impairment, seizures, } \\
\text { peripheral neuropathy }\end{array}$ & & $\begin{array}{l}\text { Brain stem RF, demyelination, basal } \\
\text { ganglia calcification }\end{array}$ \\
\hline $\begin{array}{l}32 \text { Male (current } \\
\text { case) }\end{array}$ & $\begin{array}{l}\text { AIDS, lymphoma, CMV } \\
\text { [anti-retroviral/toxo.] }\end{array}$ & & + & $\begin{array}{l}\text { Brain stem RF, CMV infection, } \\
\text { lymphoma }\end{array}$ \\
\hline $66 \mathrm{Male}^{27}$ & Stokes-Adams attacks, DM & $\begin{array}{l}\text { Dementia, seizures, pseudobulbar palsy, } \\
\text { spasticity }\end{array}$ & & $\begin{array}{l}\text { Brain stem and cerebellar RF, multiple } \\
\text { infarcts }\end{array}$ \\
\hline 70 Male $^{11}$ & $\begin{array}{l}\mathrm{COAD} \text {, cor pulmonale, } \mathrm{AF}, \mathrm{DM}, \mathrm{PUD}, \\
\text { myelofibrosis }\end{array}$ & & + & Predominantly brain stem RF \\
\hline 19 Female $^{27}$ & $\begin{array}{l}\text { Reticulum cell sarcoma [chemotherapy, } \\
\text { steroids] }\end{array}$ & & + & $\begin{array}{l}\text { Brain stem and upper cervical cord RF, } \\
\text { metastatic reticulum cell sarcoma }\end{array}$ \\
\hline 54 Female $^{27}$ & Metastatic melanoma [chemotherapy] & Dementia, ataxia & & Brain stem RF, melanoma \\
\hline 65 Female $^{11}$ & $\begin{array}{l}\text { Ovarian carcinoma, DVT, ARF } \\
\text { [chemotherapy] }\end{array}$ & & + & Predominantly brain stem RF \\
\hline$\S 78 \mathrm{Female}^{17}$ & $\begin{array}{l}\text { Rheumatic fever, hypertension, } \mathrm{OA} \text {, } \\
\text { cataracts }\end{array}$ & TIA, parkinsonism, dementia & & Cerebral infarction, brain stem RF \\
\hline 82 Female $^{27}$ & $\begin{array}{l}\text { Hypertension, CAD, gallstones, renal } \\
\text { failure, GI bleed }\end{array}$ & & + & Diffuse(?) RF, pontine infarction \\
\hline 85 Female $^{28}$ & DM, CAD, hypertension, hypoglycaemia & & + & $\begin{array}{l}\text { Brain stem RF, early Alzheimer's } \\
\text { disease, Lewy bodies in locus coeruleus } \\
\text { and raphe nuclei }\end{array}$ \\
\hline \multicolumn{5}{|c|}{$\begin{array}{l}\text { RFE, Rosenthal fibre encephalopathy; RF, Rosenthal fibres; CAD, coronary artery disease; AF, atrial fibrillation; GI, gastrointestinal; DM, diabetes mellitus; } \\
\text { ARF, acute renal failure; PUD, peptic ulcer disease; ARDS, adult respiratory distress syndrome; COAD, chronic obstructive airways disease; DVT, deep } \\
\text { vein thrombosis; OA, osteoathritis; TB, tuberculosis; i.v., intravenous; anti-retroviral/toxo., anti-retroviral, and anti-toxoplasmosis therapy. } \\
\S \text { Possible RFE (see text for details). } \\
\text { ^These pathological changes were found on brain biopsy. } \\
\text { The numeric reference to each case is indicated in superscript. }\end{array}$} \\
\hline
\end{tabular}

of Alexander's disease, on the basis of the compatible clinical findings for which there was no other pathological explanation.

In rare instances the pathological appearance of Alexander's disease may be mimicked by antemortem exposure to neurotoxins, as in the case of the 22 year old man who was deemed to have Rosenthal fibre encephalopathy at postmortem examination rather than Alexander's disease, because the co-occurrence of demyelination could be explained by a history of solvent abuse. ${ }^{12}$ It could be argued that the case of progressive parkinsonism with Rosenthal fibres, tentatively labelled as senile onset Alexander's disease by the authors, ${ }^{17}$ merits a distinct category of its own, but it would be more appropriate to avoid classifying this case as a separate nosological entity unless additional cases with identical clinicopathological findings are identified. We have reclassified this case as possible Rosenthal fibre encephalopathy in view of the absence of demyelination, the preponderance of Rosenthal fibres in the brain stem, and the lack of any of the typical clinical features of Alexander's disease (see table 1).

The recent discovery of spontaneous, non-conservative, dominant point mutations in the open reading frame of the GFAP gene in infantile onset Alexander's disease may be an important step towards elucidating the molecular genetic basis of this disease ${ }^{18}$ Of 13 patients with pathologically confirmed, infantile or childhood onset Alexander's disease, GFAP mutations involving arginine residues were found in $12 .{ }^{18}$ In the latter series, the ratio of male to female cases was $0.6: 1$, similar to the gender ratio of adult onset Alexander's disease, suggesting that across the age spectrum the disease may be more frequent in females than in males. In childhood and juvenile onset cases, the pathological changes correlate well 
with abnormalities on MRI, which include frontal predominance of white matter abnormalities and atrophy of subcortical structures. ${ }^{19}$ The presence of GFAP mutations in 14 of 15 patients with probable Alexander's disease who were diagnosed on the basis of compatible clinical presentations and suggestive radiological abnormalities, confirmed that the mutations are a reliable molecular marker for infantile forms of the disease. ${ }^{20}$ The potential of screening for GFAP mutations in suspected childhood onset cases broadens the antemortem diagnostic modalities available beyond MRI in this subgroup. $^{19}$

Two cases in the latter molecular genetic studies, one with onset in childhood and the other with infantile onset, were still alive at follow up aged 48 years and 20 years, respectively. ${ }^{18} 20$ These cases have not been included in the table because of the onset of disease prior to adulthood. Consistent with a distinct pathophysiological mechanism for adult onset Alexander's disease, mutations in GFAP have yet to be shown in any cases of adult onset, including the cases cited in table 1. In only a single case of adult onset Alexander's disease, aged 45 years at onset, has a limited analysis of the GFAP gene excluded the presence of any of the known mutations. ${ }^{21}$ In this, as in other cases of adult onset disease, it will be important to sequence the whole gene to exclude the possibility of novel mutations. Other mechanisms in adult onset Alexander's disease and Rosenthal fibre encephalopathy that have yet to be explored include GFAP gene polymorphisms and mutations in genes encoding proteins that are known to interact with GFAP, such as the $\alpha \beta$-crystallin gene.

This is the first description of Rosenthal fibre encephalopathy in a patient with AIDS and who showed no neurological impairment despite having CNS lymphoma and cytomegalovirus infection. Rosenthal fibre formation in this setting has a number of possible explanations. First, overexpression of GFAP in transgenic mice is sufficient to induce the formation within astrocytes of protein aggregates that are biochemically and morphologically indistinguishable from Rosenthal fibres. ${ }^{22}$ The underlying viral infection or neoplastic disorder may have provoked an over-expression of the GFAP gene resulting in the formation of Rosenthal fibres. Second, polymorphisms in the GFAP gene favouring alterations in the tertiary structure of the protein that promote GFAP aggregation or enhanced stability are possibilities that need to be explored. Third, it is interesting to note that five of the 11 cases of Rosenthal fibre encephalopathy, including this one, were associated with immunosuppression. At present it is unclear whether there is a causal link.

\section{NOTE ADDED IN PROOF}

Since the submission of this article, it has been reported for the first time that novel missense mutations in the GFAP gene have been detected in two Japanese brothers with hereditary adult onset Alexander's disease, with postmortem confirmation in one case. This finding extends the role of pathogenic mutations in GFAP to the aetiology of familial subtypes of adult onset Alexander's disease (Namekawa M, Takiyama Y, Aoki Y, et al. Identification of GFAP gene mutation in hereditary adult-onset Alexander's disease. Ann Neurol 2002;52:779-85).

\section{Authors' affiliations}

J Jacob, Department of Neurology, Derriford Hospital, Plymouth, UK N J Robertson, D A Hilton, Department of Histopathology and Neuropathology, Derriford Hospital

Correspondence to: Dr J Jacob, Department of Neurology, Derriford
Hospital, Derriford Road, Plymouth, Devon PL6 8DH, UK; si.jacob@virgin.net

Received 27 August 2002

Accepted 11 December 2002

\section{REFERENCES}

1 Alexander A. Progressive fibrinoid degeneration of fibrillary astrocytes associated with mental retardation in a hydrocephalic infant. Brain 1949;72:373.

2 Seil FJ, Schochet SS Jr, Earle KM. Alexander's disease in an adult. Report of a case. Arch Neurol 1968;19:494-502

3 Walls TJ, Jones RA, Cartlidge N, et al. Alexander's disease with Rosenthal fibre formation in an adult. J Neurol Neurosurg Psychiatry 1984;47:399-403

4 Herndon RM, Rubinstein LJ, Freeman JM, et al. Light and electron microscopic observations on Rosenthal fibers in Alexander's disease and in multiple sclerosis. J Neuropathol Exp Neurol 1970;29:524-51.

5 Spalke G, Mennel HD. Alexander's disease in an adult: clinicopathologic study of a case and review of the literature. Clin Neuropathol 1982;1:106-12.

6 Iwaki T, Kume-lwaki A, Liem RK, et al. Alpha B-crystallin is expressed in non-lenticular tissues and accumulates in Alexander's disease brain. Cell 1989:57:71-8.

7 Johnson AB, Bettica A. On-grid immunogold labeling of glial intermediate filaments in epoxy-embedded tissue. Am J Anat 1989;185:335-41

8 Goldman JE, Corbin E. Rosenthal fibers contain ubiquitinated alpha B-crystallin. Am J Pathol 1991;139:933-8.

9 Iwaki T, Iwaki A, Tateishi J, et al. Alpha B-crystallin and 27-kd heat shock protein are regulated by stress conditions in the central nervous system and accumulate in Rosenthal fibers. Am J Pathol 1993; 143:487-95.

10 Dinda AK, Sarkar C, Roy S. Rosenthal fibres: an immunohistochemical, ultrastructural and immunoelectron microscopic study. Acta Neuropathol 1990;79:456-60

11 Riggs JE, Schochet SS Jr, Nelson J. Asymptomatic adult Alexander's disease: entity or nosological misconception? Neurology 1988;38:152-4.

12 Wilson SP, Al-Sarraj S, Bridges LR. Rosenthal fiber encephalopathy presenting with demyelination and Rosenthal fibers in a solvent abuser: adult Alexander's disease? Clin Neuropathol 1996;15:13-16.

13 Herndon RM. Is Alexander's disease a nosologic entity or a common pathologic pattern of diverse etiology? J Child Neurol 1999;14:275-6.

14 Hilton DA, Love S, Fletcher A, et al. Absence of Epstein-Barr virus RNA in multiple sclerosis: a study using in situ hybridisation. J Neurol Neurosurg Psychiatry 1994;57:975-6.

15 Howard RS, Greenwood R, Gawler J, et al. A familial disorder associated with palatal myoclonus, other brainstem signs, tetraparesis, ataxia and Rosenthal fibre formation. J Neurol Neurosurg Psychiatry 1993;56:977-81.

16 Schwankhaus JD, Parisi JE, Gulledge WR, et al. Hereditary adult-onset Alexander's disease with palatal myoclonus, spastic paraparesis, and cerebellar ataxia. Neurology 1995;45:2266-71.

17 Friedman JH, Ambler M. Progressive parkinsonism associated with Rosenthal fibers: senile-onset Alexander's disease? Neurology 1992;42:1733-5

18 Brenner $M$, Johnson AB, Boespflug-Tanguy $O$, et al. Mutations in GFAP, encoding glial fibrillary acidic protein, are associated with Alexander disease. Nat Genet 2001:27:117-20.

19 van der Knaap MS, Naidu S, Breiter SN, et al. Alexander disease: diagnosis with MR imaging. Am J Neuroradiol $2001 ; 22: 541-52$.

20 Rodriguez D, Gauthier F, Bertini E, et al. Infantile Alexander disease: spectrum of GFAP mutations and genotype-phenotype correlation. Am J Hum Genet 2001:69:1 134-40.

21 Messing A, Goldman JE, Johnson AB, et al. Alexander disease: new insights from genetics. J Neuropathol Exp Neurol 2001;60:563-73.

22 Messing A, Head MW, Galles K, et al. Fatal encephalopathy with astrocyte inclusions in GFAP transgenic mice. Am J Pathol 1998; 152:391-8.

23 Klein H. Alexander'sche Krankheit bei einer Erwaschsenen. Zentralb/ ges Neurol Psychiat 1970;197:338.

24 Duckett S, Schwartzman RJ, Osterholm J, et al. Biopsy diagnosis of familial Alexander's disease. Pediatr Neurosurg 1992;18:134-8.

25 Kepes JJ, Ziegler DK. Alexander's disease in an adult (leukodystrophy with Rosenthal fibres). Missouri Med (Suppl) 1972;69:23-5

26 Tihen WS. Central pontine myelinolysis and Rosenthal fibers of the brainstem. Association with emaciation and prolonged intravenous hyperalimentation. Neurology 1972;22:710-16.

27 Mastri AR, Sung JH. Diffuse Rosenthal fiber formation in the adult: a report of four cases. J Neuropathol Exp Neurol 1973;32:424-36.

28 Soffer D, Horoupian DS. Rosenthal fibers formation in the central nervous system. Its relation to Alexander's disease. Acta Neuropathol (Berl) 1979;47:81-4. 